\title{
SNAPSHOT OF E-GOVERNMENT APPLICATIONS ACCEPTANCE AMONG THE URBAN POOR COMMUNITIES AND ITS RELATIONSHIP WITH AGE, GENDER, EDUCATION AND INCOME IN MALAYSIA
}

\author{
Ainin Sulaiman*, Siti Qhairunissa Ramli, Nor Shahida Azali, Nor Ain Abd. Rani, \\ Haryana Rozana Abdul Rahim \& Nadhirah Nazarudin \\ ${ }^{*}$ First author \\ UM Research Clusters, Institute of Research Management and Services, \\ University of Malaya, Kuala Lumpur, Malaysia \\ (ainins@um.edu.my;sitiqhairunissa@um.edu.my;shida_wan@um.edu.my;norainabdr \\ ani@um.edu.my; hrozana@um.edu.my; nadhirahnazarudin@um.edu.my) \\ DOI: https://doi.org/10.22452/jati.vol24no2.2
}

\begin{abstract}
Many countries, including Malaysia, have implemented e-government applications as part of their efforts to improve the efficiency and accountability of the public authorities. E-government connects government agencies with citizens, who can conduct transactions regardless of their age, gender, education and income, requiring only a device that can access the Internet. The objectives of this paper are twofold: i) to examine the level of usage of e-governments; and ii) to analyse the relationships between age, gender, education, income, level of usage and user (citizen) satisfaction with e-government among selected poor urban communities. Empirical data were collected from four poor urban communities via a survey questionnaire. The findings illustrate that usage is still rather low, and additional effort should, therefore, be made by the relevant agencies to increase usage. Of the ten applications studied, more than 50 percent of the respondents used only one or two applications; these were the applications most relevant to them, such as those from BR1M and the National Registration Department. It was found that education and income significantly influenced e-government usage, while age and gender did not. The results also indicate that a large percentage of users were satisfied with egovernment applications, although there were no correlations between age, gender, education, income and satisfaction.
\end{abstract}

Keywords: age, education, e-government, gender, income, satisfaction, urban communities, usage 


\section{Introduction}

The implementation of e-government in Malaysia began in 1996, with the creation of the Multimedia Super Corridor (MSC). This e-government initiative was implemented and monitored by the Malaysia Administrative Modernisation and Management Planning Unit (MAMPU), a central agency in the Malaysian Government (Alias, Idris, Ashaari, \& Kasimin, 2011). As highlighted by Suki and Ramayah (2010), e-government was one of the seven flagship applications introduced in the MSC. The Malaysian government has implemented several egovernment platforms since the inception of the MSC. There are several types of e-government: government-to-government (G-to-G, between various government agencies), government-to-business (G-to-B, between government agencies and private enterprises) and government-to-citizens (G-to-C, between government agencies and citizens) (Horan, Abhichandani, \& Rayalu, 2006). This study focuses on G-to-C applications, as they can be used by a wider range of Malaysian communities, while G-to-G and G-to-B applications are more relevant to certain sectors of the Malaysian community. Communities in Malaysia generally are categorised based on their yearly household income (Naira \& Sagaran, 2015). There are three income groups: the top 20 percent (T20), the middle 40 percent (M40) and the bottom 40 percent (B40). According to Tan Yi Liang, B40 refers to households with a monthly income of RM3,900 and below (Tan Yi Liang, 2016). It has also been reported that 63.1 percent of B40 households are in urban areas, and this study, therefore, focuses on B40 urban communities. The objectives of this study are to investigate the level of e-government usage and to analyse the relationships between age, gender, education, income, level of usage and user (citizen) satisfaction with e-government applications in selected poor urban communities. This paper examines 10 e-government projects in Malaysia: BR1M, e-Kasih, Zakat, JobsMalaysia, the National Registration Department, e-Jakim, eRezeki, e-Usahawan, Jabatan Pengangkutan Jalan (JPJ) and SPA8i.

\section{Background}

\section{E-government Platforms in Malaysia}

The Malaysian government has implemented many e-government platforms; those specifically aimed at poorer people include BR1M, e-Kasih, and e-Rezeki, while Zakat, JobsMalaysia, the National Registration Department of Malaysia, eJakim, e-Usahawan, JPJ and SPA8i are aimed at all Malaysian citizens. The sixth prime minister of Malaysia devised the BR1M (or 'Bantuan Rakyat 1 Malaysia') programme as part of the government's effort to ease the burden on the lowerincome group in the country (Lembaga Hasil Dalam Negeri Malaysia [LHDN], 
2017). This programme is also known as 1 Malaysia People's Aid, and was created in 2012. This aid is available to Malaysians, either female or male, who have responsibility for a household, and may include senior citizens, single individuals (divorced or unmarried people, or single parents) with dependencies, single parents (father or mother) and married people (including married couples who are still living with a parent).

e-Kasih is the National Poverty Data Bank and contains information on poverty that includes individual profiles, aid agency programmes/assistance received by the household head (KIR) and household members (AIRs), requests for assistance and monitoring of the effectiveness of any programmes or assistance accepted (Portal Pembasmian Kemiskinan, 2018). The e-Kasih data component consists of basic KIRs and AIRs, location, home, education, skills and jobs information, property ownership, health, income and assistance. Online users of e-Zakat can review their Zakat payment information throughout the year, print Zakat statements, update their personal information, and make direct payments to Zakat via e-Zakatpay (My Government, 2018). JobsMalaysia is an automated online job matching system provided by the Ministry of Human Resources (Kementerian Sumber Manusia, 2018). It is one of three core modules provided by the Electronic Labour Exchange (ELX), and was launched by the Minister of Human Resources, YB Datuk Dr. Wira Fong Chan Onn, on the 30th May 2002. The National Registration Department of Malaysia (2016) provides nine online services including applications for Mykad/MyPR/MyKas, applications for replacement MyKad, and applications for MyKid. e-Jakim is a service that gives information about eleven JAKIM authorities, such as e-Quran, e-Hadith, e-Solat and others (Jabatan Kemajuan Islam Malaysia [JAKIM], 2018). The e-Rezeki programme enables citizens, and especially low-income groups, to generate additional income by undertaking digital assignments via an online crowdsourcing platform (Malaysia Digital Economy Corporation [MDEC], 2018). Participants are matched with digital work that corresponds to their respective skills. e-Usahawan is a programme that allows users the opportunity to gain business knowledge online and helps them to grow their businesses using a digital platform. It is an MDEC initiative to encourage digital entrepreneurship value and knowledge among youths and micro-entrepreneurs. Participants are exposed to digital marketing techniques that are effective, practical and relevant to current users. JPJ provides online applications for consumers, such as summons checking, road tax expiry checking and other services (Jabatan Pengangkutan Jalan [JPJ], 2018). SPA8i has developed the mySPA8i mobile application in collaboration with MAMPU, which offers an alternative to the public service employment registration system (SPA8i). mySPA8i consists of several modules, 
such as a MyID registration, password resetting, information on applicants, academic matters, curricula and other aspects, the servicing officer, the position applied for, and the petitioner's declaration.

\section{Literature Review}

The Internet has changed the way in which governments interact with citizens and businesses, and has also had a significant impact on government administration and operations (Ramli, 2012). The Internet has also become a frequently used channel for public service take-up in all services (United Nations, 2012). Usage of government services is found to be strongly contingent on fast and reliable Internet connections (United Nations, 2012). Use of the prefix 'electronic' to name a phenomenon (for example, the label 'electronic government') was widespread in the early days of the Internet in the 1990s, and similar concepts such as 'electronic business', 'electronic commerce', and 'electronic democracy', were created, among others. In those early days, the term 'electronic' suggested a modern, novel, and future-oriented undertaking supported by ICT. E-government involves the use of ICTs to promote more efficient and effective government, make government services more accessible, allow greater public access to information, and make governments more accountable to citizens (Sarrayrih \& Sriram, 2015).

The development of e-government capabilities is an important undertaking since it is not only rapidly changing the way that governments supply information, deliver services, and deal with the public, but is also becoming an integral part of government strategies (Zhang, Xu, \& Xiao, 2014). Sorn-in, Tuamsuk, and Chaopanon (2015) showed that the development of ICT is an important tool for driving and developing the economy, society and lifestyles. The promotion and development of e-government platforms require a national policy on the use of ICT as a tool to enhance the capability and efficiency of public management and services for citizens. Currently, government agencies have given priority to the development of e-government by recognising the benefits and value of ICT innovation. E-government is believed to represent a means of effective governance and citizen participation, at both national and local levels. It has the potential to improve public management and to increase efficiency, transparency and accountability (Abdullah, Mansor, \& Hamzah, 2013). The benefits arising from the use and application of e-government in developing countries are the same as those in developed countries (Ndou, 2004). The Malaysian government has stated that the goals of online government services are to increase customer satisfaction through an initiative to bring together public services, to meet the needs of citizens through more 
transparency, competitiveness and competence of government services, to improve the accessibility of online services to government service transformation of the new millennium, and finally to improve service delivery in the global arena. The implementation of e-government benefits both citizens and government in many ways, as long as the effectiveness of the delivery system and the citizens' level of usage of the services are continuously improved. Firstly, e-government improves efficiency since the use of information technology generates improvements in mass processing tasks and public administration operations. Hence, e-government platforms can generate savings in terms of data collection and transmission. Another form of efficiency is data sharing between government agencies. e-government also improves services, since the main element driving the reform of government operations is the adoption of a customer-focused approach. e-government platforms are developed based on the best understanding of citizen requirements in order to provide a seamless online service and thus improve traditional government services (Ahmad \& Othman, 2006).

Although e-government services are offered to all citizens, the extent of usage tends to differ depending on demographic profile, such as education, age, occupation and living area (UN Report, 2012). In their study of Australian and New Zealand citizens by Gauld, Goldfinch, and Horsburgh (2010) identified significant relationships between e-government usage, age and education. This finding was supported by Sharma (2015) who studied citizens in Oman, and Venkatesh, Sykes, and Venkatraman (2014) who studied e-government usage in rural India. Citizens who are older or less educated tend to use e-government less and tend to be less receptive to the usage of technology (Gauld, Goldfinch, \& Horsburgh, 2010). Citizens younger than 35 years old have been exposed to the use of technology since childhood, and have therefore embraced technology, and particularly the Internet, as part of their daily lives. Citizens who are more educated tend to use technology more, and hence it can be expected that they are more receptive to the use of e-government applications (Sharma, 2015). Reddick and Anthopoulos (2014) and Venkatesh et al. (2014) found that gender and income influenced the usage of e-government in Canada and India, respectively. They found that females and low-income citizens use e-government platforms less often. However, Gauld et al. (2010) found that gender and income level did not significantly affect e-government usage. Based on the above discussion, the following hypotheses are presented:

H1, H2, H3, H4: age, education, gender

Income is positively related to e-government usage 
Generally, after studying the usage of any system, it is beneficial to study whether the users (in this case, citizens) are satisfied with the e-government applications they have used. Alzahrani, Al-Karaghouli, and Weerakkody (2017) relate satisfaction to whether a citizen was able to achieve his/her needs through using a particular e-government application. Several studies have focussed on the interrelationship between citizens' satisfaction and use behaviour Alzahrani et al. (2017), Colesca and Dobrica (2008) although few have examined the relationship between satisfaction and demographic profiles. One of the objectives of this study is, therefore, to investigate this aspect, in order to fill the current gap in the literature. The following hypotheses are proposed for empirical testing in relation to poor urban communities:

$\mathrm{H} 5, \mathrm{H6}, \mathrm{H7}$, H8: Satisfaction with e-government usage is positively associated with age education gender income

\section{Methodology}

This study uses a survey questionnaire to collect empirical data. This questionnaire consists of two main sections: the first consists of questions related to factors influencing e-government usage, while the second section consists of questions related to demographics, type of e-government platforms used and the level of satisfaction. This paper analyses and presents data from the second section of the questionnaire, since the aim of this study is to examine the level of usage, the user-profiles and the level of satisfaction of the users among B40 urban communities. The demographics used in this study are based on Venkatesh et al. (2014), while the types of e-government applications were based on ten applications implemented by the Malaysian government. Items for measuring satisfaction were adopted from (Colesca \& Dobrica, 2008).

\section{Data Collection and Data Analysis}

In this study, the target sample was Malaysians living within the Kuala Lumpur area (the capital city of Malaysia) with a monthly household income of RM3,800 or less. This group of Malaysians is known as the B40 group. The B40 group were chosen because they generally have less access to IT infrastructure, and are therefore a better sample in terms of reflecting the usage of e-government services. The questionnaires were distributed to households living in The People's Poorest Housing Programme (PPRT) areas in Kuala Lumpur; these areas are reserved for the B40 group, and this ensured that only the target population were included in the survey. One thousand questionnaires were distributed in four PPRT areas in Kuala Lumpur, with 250 questionnaires 
distributed in each area. Potential respondents were approached personally, and before they were given the questionnaire, the aim of the survey was explained to them to ensure that correct responses were collected. Most of the respondents filled in the questionnaire on the spot, while some opted to return the survey later at an agreed location, such as a nearby shop or place of worship. Data collection was carried out over a period of three months. After removing questionnaires with incomplete responses, 778 questionnaires were used for analysis.

\section{Results}

As this study focuses on investigating the current state of ICT usage in delivering government initiatives and programmes to the B40 group of users, it was important to assess the demographic characteristics of the B40 households in the Kelang Valley and their usage of e-government services. The demographic characteristics of the respondents to the survey are presented in Table 1 below.

Table 1: Profile of Respondents

\begin{tabular}{cccc}
\hline Category & Items & No. $\mathbf{( N =}$ 778) & Percent (\%) \\
\hline \multirow{2}{*}{ Gender } & Male & 481 & 61.8 \\
& Female & 297 & 38.2 \\
\hline \multirow{3}{*}{ Age } & $18-25$ years & 116 & 14.9 \\
& $26-35$ years & 296 & 38.0 \\
& $36-45$ years & 226 & 29.0 \\
& $46-55$ years & 100 & 12.9 \\
& $>55$ years & 40 & 5.1 \\
\hline \multirow{5}{*}{ Education } & Primary School & & 1.8 \\
& High School & 14 & 54.5 \\
& Certificate/ & 424 & 36.9 \\
& Diploma & 287 & 5.5 \\
& Graduate & 43 & 1.3 \\
Income per & Bachelor/Degree & 10 & 8.1 \\
month & Others & 63 & 37.1 \\
& RM1,000 & 289 & 43.8 \\
& RM1,001-RM2,000 & 341 & 10.9 \\
\hline
\end{tabular}

We found that a high percentage of the respondents were using e-government applications: 577, 331 and 238 respondents used the BR1M, Road Transport Department platforms and SPA8i, respectively (Table 2). 
Table 2: Applications Used by Respondents

\begin{tabular}{lcc}
\hline Applications & No. $\mathbf{( N =}$ 778) & Percent (\%) \\
\hline BRIM & 577 & 74.2 \\
E-KASIH & 110 & 14.1 \\
ZAKAT & 144 & 18.5 \\
JOB MALAYSIA & 223 & 28.7 \\
NATIONAL REGISTRATION DEPARTMENT & 151 & 19.4 \\
E-JAKIM & 45 & 5.8 \\
E-REZEKI & 33 & 4.2 \\
E-USAHAWAN & 104 & 13.4 \\
ROAD TRANSPORT DEPARTMENT & 331 & 42.5 \\
SPA8i & 238 & 30.6 \\
\hline
\end{tabular}

Further analysis was carried out to determine the level of usage, which was divided into three categories (low, medium and high) using the quartile function in SPSS Version 23 (Table 3). It was found that the level of e-government usage was low, as more than 50 percent of the respondents used only one or two applications.

Table 3: Level of Usage

\begin{tabular}{ccc}
\hline Usage & Frequency & Percent (\%) \\
\hline 1-2 (Low) & 455 & 58.5 \\
3-4 (Medium) & 248 & 31.9 \\
3.00 (High) & 75 & 9.6 \\
Total & $\mathbf{7 7 8}$ & $\mathbf{1 0 0 . 0}$ \\
\hline
\end{tabular}

Based on the hypotheses proposed above, a correlation analysis was carried out to test the relationship (Table 4). From Table 4, it can be seen that age and gender were not significantly related to e-government usage, and thus $\mathrm{H} 1$ and $\mathrm{H} 3$ were not supported. On the other hand, the results illustrated that $\mathrm{H} 2$ and $\mathrm{H} 4$ were supported since education and income did influence e-government usage. 
Table 4: Correlations

\begin{tabular}{|c|c|c|c|c|c|c|}
\hline & Gender & Age & Education & $\begin{array}{l}\text { Monthly } \\
\text { Income }\end{array}$ & $\begin{array}{c}\text { E- } \\
\text { government } \\
\text { Usage }\end{array}$ & $\begin{array}{l}\text { E-government } \\
\text { Satisfaction }\end{array}$ \\
\hline Gender & 1 & $.116^{-}$ & $.090^{*}$ & $-.164^{* *}$ & .008 & .022 \\
\hline Age & .001 & 1 & $-.148^{* *}$ & $.089^{*}$ & -.005 & -.056 \\
\hline Education & .012 & .000 & 1 & $.273^{* *}$ & $.182^{* *}$ & .013 \\
\hline $\begin{array}{l}\text { Monthly } \\
\text { Income } \\
\text { E- }\end{array}$ & .000 & .013 & .000 & 1 & $.136^{* *}$ & .057 \\
\hline $\begin{array}{l}\text { government } \\
\text { Usage }\end{array}$ & .819 & .879 & .000 & .000 & 1 & -.009 \\
\hline $\begin{array}{l}\text { E- } \\
\text { government } \\
\text { Satisfaction }\end{array}$ & .546 & .119 & .724 & .113 & .009 & 1 \\
\hline $\begin{array}{l}* * \text { Correlatic } \\
\text { at the } 0.05 \text { le } \\
\text { Figures in D }\end{array}$ & $\begin{array}{l}\text { n is signif } \\
\text { vel ( } 2 \text {-taile } \\
\text { lagonal ror }\end{array}$ & $\begin{array}{l}\text { icant a } \\
\text { d). } \\
\text { w indic }\end{array}$ & $\begin{array}{l}\text { the } 0.01 \text { lev } \\
\text { cates } p \text { value }\end{array}$ & vel (2-tail & *. Correla & is significant \\
\hline
\end{tabular}

From Table 5, it can be seen that the users were generally happy with the egovernment applications that they used, with more than 89 percent reporting that they were satisfied with them. Further analysis was conducted to test the relationship between satisfaction with e-government applications and the four demographic aspects of age, education, gender and income. The results are presented in Table 4 and show that there is no correlation between the four demographic profiles and user satisfaction. Thus, H5, H6, H7 and H8 were rejected.

Table 5: Level of Satisfaction of E-Government Applications

\begin{tabular}{ccc}
\hline Level of Satisfaction & Frequency & \% \\
\hline Very Dissatisfied & 1 & .1 \\
Dissatisfied & 3 & .4 \\
Neutral & 87 & 11.2 \\
Satisfied & 476 & 61.2 \\
Very Satisfied & 211 & 27.1 \\
\hline Total & $\mathbf{7 7 8}$ & $\mathbf{1 0 0 . 0}$ \\
\hline
\end{tabular}




\section{Discussion}

As mentioned at the beginning of the paper, the objectives of this study are to investigate the level of e-government usage (namely BR1M, e-Kasih, Zakat, JobsMalaysia, National Registration Department, e-Jakim, e-Rezeki, e-Usahawan, JPJ and SPA8i) and to analyse the relationships between age, gender, education, income, level of usage and user (citizen) satisfaction with e-government platforms among selected poor urban communities. Data were collected from 778 citizens using e-government applications. The results indicated the majority of the citizens used the BR1M, Road Transport Department and SPA8i applications since these were the most relevant to this population. All the citizens in this study are eligible to obtain financial aid from the government under the BR1M scheme, and can thus use the e-BR1M application to obtain updates on their personal information. All Malaysian citizens need to use the Road Transport Department application to register vehicles and renew road tax. It is hypothesised here that most of the citizens surveyed have some form of vehicle, and thus the usage of this application is rather high. With regards to the SPA8i application, citizens among the selected urban poor use the public service employment registration system to ease their employment seeking activities.

The usage of e-government applications was then categorised into three levels, low, medium and high, using the quartile function in SPSS Version 23. It was surprising to find that the level of e-government usage was low among the citizens surveyed since they tended only to use those applications that were more applicable to them, such as the BR1M, Road Transport Department and SPA8i applications. We tested the relationships between age, gender, education and income, and the results showed that age was not significantly related to egovernment usage. This finding contradicts those of Gauld et al. (2010), Sharma (2015) and Venkatesh et al. (2014) as these authors found age to be significantly related to e-government usage, with younger citizens tending to use the egovernment applications more than older citizens. We also found that gender was not significantly correlated with e-government usage. This is consistent with the study of Gauld et al. (2010) although it contradicts the results of Reddick and Anthopoulos (2014) and Venkatesh et al. (2014) who found that males were more frequent users of e-government applications than females. With regard to the relationship between usage and education, we found the relationship to be coherent with that identified by Gauld et al. (2010), Sharma (2015) and Venkatesh et al. (2014) the more educated citizens were, the more likely they were to use egovernment applications. Income was also discovered to be significantly related to usage, as established by Reddick and Anthopoulos (2014) and Venkatesh et al. (2014). Citizens with lower income tended to use e-government applications less 
than those with higher income within the poor urban community. We attempted to analyse the relationship between satisfaction with e-government usage and demographic profile and found that there was no significant relationship. This is probably due to the fact that almost all (95.5\%) of the citizens were either satisfied or very satisfied with or neutral (response) towards the applications.

\section{Conclusion}

In general, it can be concluded that citizens use e-government applications that are relevant and applicable to them; thus, when planning new applications, the government must give priority to those that are relevant to the majority rather than a particular segment of the total population. The majority of respondents used only one or two applications, and it is assumed that this was due to the lack of necessity to use other applications among the poor urban community. Future research should examine a different segment of the community, such as the M40 or T20 groups. We found age and gender to be insignificant factors in determining e-government usage but found education and income to be significant. The relevant authorities can consider these findings when planning new applications. As in all studies, this study has certain limitations; the focus of the study is on poor urban communities, and future studies should include all economic segments of the population.

\section{Acknowledgements}

The authors would like to thank the Equitable Society Research Cluster, University of Malaya for providing the funding to conduct this research (grant number: UMRG RP 032C-16SBS). The authors would also like to thank the professional editing company for their service. In addition, the authors would like to express their gratitude to the reviewers for their constructive comments.

\section{References}

Abdullah, N. R. W., Mansor, N. B., \& Hamzah, A. (2013). Keeping ahead of the game: Innovations and challenges in e-government in Malaysia. The Economic and Labour Relations Review, 24(4), 549-567.

Ahmad, M., \& Othman, R. (2006). Implementation of electronic government in Malaysia: The status and potential for better service to the public. Public Sector ICT Management Review, 1(1), 2-10.

Alias, E. S., Idris, S. H. M., Ashaari, N. S., \& Kasimin, H. (2011). Evaluating egovernment services in Malaysia using the EGOVSAT model. In 
Proceedings of the 2011 International Conference on Electrical Engineering and Informatics (pp. 1-5). June 19, 2018, from https://ieeexplore.ieee.org/stamp/stamp.jsp?tp=\&arnumber $=6021740$

Alzahrani, L., Al-Karaghouli, W., \& Weerakkody, V. (2017). Analysing the critical factors influencing trust in e-government adoption from citizens' perspective: A systematic review and a conceptual framework. International Business Review, 26(1), 164-175.

Colesca, S. E., \& Dobrica, L. (2008). Adoption and use of e-government services: The case of Romania. Journal of applied research and technology, 6(3), 204217.

Gauld, R., Goldfinch, S., \& Horsburgh, S. (2010). Do they want it? Do they use it? The 'Demand-Side' of e-Government in Australia and New Zealand. Government Information Quarterly, 27(2), 177-186.

Horan, T. A., Abhichandani, T., \& Rayalu, R. (2006). Assessing user satisfaction of e-government services: Development and testing of quality-in-use satisfaction with advanced traveler information systems (ATIS). In Proceedings of the 39th Annual Hawaii International Conference on System Sciences (HICSS'06) (Vol. 4) (pp. 1-10). Retrieved June 19, 2018, from https://ieeexplore.ieee.org/document/1579457

Jabatan Kemajuan Islam Malaysia (JAKIM). (2018). E-Jakim. Retrieved June 19, 2018, from http://www.islam.gov.my/45-e-jakim

Jabatan Pengangkutan Jalan (JPJ). (2018). Retrieved June 19, 2018, from http://www.jpj.gov.my/

Kementerian Sumber Manusia. (2018). jobMalaysia. Retrieved June 19, 2018, from https://www.jobsmalaysia.gov.my/jobsmy/home

Lembaga Hasil Dalam Negeri Malaysia (LHDN). (2017). Bantuan Rakyat 1 Malaysia. Retrieved June 19, 2018, from https://br1m.hasil.gov.my/

Malaysia Digital Economy Corporation (MDEC). (2018). e-Rezeki. Retrieved June 19, 2018, from https://erezeki.my/

My Government. (2018). E-Zakat Pay. Retrieved June 19, 2018 from https://www.malaysia.gov.my/public/cms/article/page/545/

Nair, S., \& Sagaran, S. (2015). Poverty in Malaysia: Need for a paradigm shift. Institutions and Economies, 7(3), 95-123.

National Registration Department of Malaysia. (2016). Retrieved June 19, 2018, from http://www.jpn.gov.my/en/

Ndou, V. (2004). E-government for developing countries: Opportunities and challenges. The electronic journal of information systems in developing countries, 18(1), 1-24. 
Portal Pembasmian Kemiskinan. (2018). e-Kasih. Retrieved June 19, 2018, from https://ekasih.icu.gov.my/Pages/InfoeKasih.aspx

Ramli, R. M. (2012), Hybrid approach of e-government on Malaysian egovernment experience. International Journal of Social Science and Humanity, 2(5), 366-370.

Reddick, C., \& Anthopoulos, L. (2014). Interactions with e-government, new digital media and traditional channel choices: Citizen-initiated factors. Transforming Government: People, Process and Policy, 8(3), 398-419.

Sarrayrih, M. A., \& Sriram, B. (2015). Major challenges in developing a successful e-government: A review on the Sultanate of Oman. Journal of King Saud University-Computer and Information Sciences, 27(2), 230-235.

Sharma, S. K. (2015). Adoption of e-government services: The role of service quality dimensions and demographic variables. Transforming Government: People, Process and Policy, 9(2), 207-222.

Sorn-in, K., Tuamsuk, K., \& Chaopanon, W. (2015). Factors affecting the development of e-government using a citizen-centric approach. Journal of Science E Technology Policy Management, 6(3), 206-222.

Suki, N. M., \& Ramayah, T. (2010). User acceptance of the e-government services in Malaysia: Structural equation modelling approach. Interdisciplinary Journal of Information, Knowledge, and Management, 5(1), 395-413.

United Nations (2012). United Nations e-government survey 2012: E-government for the people. New York: United Nations Department of Economic and Social Affairs. Retrieved June 19, 2018, from https://publicadministration.un.org/egovkb/Portals/egovkb/Documents/u n/2012-Survey/Complete-Survey.pdf

Tan Yi Liang (Friday, 21 Oct 2016). Budget 2017: B40 group has fastest income growth. The Star. Trom https://www.thestar.com.my/news/nation/2016/10/21/budget-2017-b40group-has-fastest-income-growth.

Venkatesh, V., Sykes, T. A., \& Venkatraman, S. (2014). Understanding e-Government portal use in rural India: Role of demographic and personality characteristics. Information Systems Journal, 24(3), 249-269.

Zhang, H., Xu, X., \& Xiao, J. (2014). Diffusion of e-government: A literature review and directions for future directions. Government Information Quarterly, 31 (4), 631-636. 